\title{
PEREBUTAN KEKUASAAN INTERNAL NU
}

\author{
Oleh : Imam Muslimin
}

\begin{abstract}
ABSTRAK
Semenjak kelahirannya, NU selalu ditandai dengan berbagai persaingan internal antar faksi yang berebut pengaruh. Buah dari persaingan itu, yang paling nyata, adalah pergeseran pembagian kekuasaan internal. Yang mana, pada saat berdirinya hingga tahun 1950-an, bagian terbesar kekuasaan dalam NU dipegang oleh faksi kiai-non politisi (syuriah), kemudian faksi politisi (tanfidiyah) mendominasi hingga paroh pertama dekade 1980-an, dan setelah itu hingga sekarang NU berada di tangan faksi "Cendekia".
\end{abstract}

\section{Pendahuluan}

Menjelang pergolakan perebutan kekuasaan di negeri ini (Indonesia) pada tahun 1965, ketika gerakan "aksi sepihak" merebak di berbagai pelosok negeri dan radikalisasi massa-militan PKI meningkat di mana-mana, D.N. Aidit, ketua PKI saat itu, menyatakan bahwa "ibu pertiwi sedang hamil tua".(Billah : 1998). Pernyataan ini ini dapat dilihat sebagai simbol yang dipergunakan untuk menegaskan pandangan faksi politik di dalam partainya tentang kondisi yang dianggapnya matang bagi suatu gerakan merebut kekuasaan yang sah. Sangat mungkin Aidit pada saat itu mengacu ke teori struktural Marxis tentang gerakan sosial, yang menekankan empat unsur penting dari kondisi yang mendukung meledaknya gerakan sosial. Keempat unsur yang ditekan oleh Marx adalah : Pertama, semakin tingginya tingkat penghisapan (eksplotasi) atas buruh; Kedua, semakin meningkatnya kesadaran revolosioner buruh; Ketiga, tersedianya organisasi buruh, dan; Keempat, meningkatnya pertikaian (konflik) antara buruh dengan kapitalis. (Irsyam : 1984).

Adalah Semelser, seorang tokoh madzhab struktural dalam Laode Ida (1995), menyatakan bahwa gerakan sosial hanya terjadi bilamana terjadi kondisi yang sangat matang. Kondisi tersebut adalah kondisi struktural yang kondusif, ketegangan struktural, tumbuh dan tersebamya keyakinan umum, adanya faktor yang mempercepat, a danya mobilisasi pertisipan untuk bertindak dan 
melemahnya kontrol sosial. Keenam unsur ini terlihat menjelang peristiwa 30 September 1965. Kondisi struktural yang kondusif pada nampak dari adanya kebebasan bagi kelompok-kelompok kepentingan (termasuk partai politik) untuk mengartikulasikan dan memperjuangkan kepentingan kelompoknya masingmasing. Ketegangan struktural antar kelompok kepentingan dan partai (terutama antara kelompok yang pro komunis termasuk faksi militer tertentu, dengan kelompok anti-komunis yang didukung oleh faksi militer yang lain) semakin menjadi-jadi. Meratanya keyakinan akan terjadinya 'goro-goro' (keadaan serba kacau). Mobilisasi massa semakin tinggi, terutama massa pro-komunis, serta kontrol sosial melemah. Ketegangan struktural dengan sangat mudah terlihat jika struktur kelompok yang tidak memperoleh privelese yang memadai (Gurr dalam Abdul Aziz Thaba :1996) dan tidak memiliki akses pada sumber-sumber kekayaan, kekuasaan, dan martabat, sehingga kelompok itu terasing secara sosial dan privelesenya secara nisbi. Akan tetapi untuk bisa memunculkan gerakan sosial, keterasingan sosial dan perampasan nisbi yang terjadi itu perlu dirasakan oleh kelompok sebagai akibat dari tatanan sosial yang tidak sah (Blumer: 1978).

\section{Pergolakan Internal NU}

Pergolakan internal NU dapat dilihat dari tatanan/struktur dan tatacara/ prosedur yang berlaku di dalam komuniti/organisasi NU dalam masalah pembagian kekuasaan di antara berbagai unsur-unsur struktural yang mendukung dan faksi-faksi internal yang saling bersaing, atau dapat pula ditinjau sifat dan proses dari struktur pengambilankeputusan di dalam organisasi, dan bagaimana berbagai faksi yang bersaing melakukan tawar-menawar dan saling tukarmenukar sumber-sumber, serta perbedaan-perbedaan yang berhubungan dengan dukungan. Sejak berdirinya hingga saat ini organisasi NU tidaklah tersusun dari unsur-unsur pendukung internal yang tidak mengalami pergeseran dan perubahan, bukan pula berada di dalam ruang eksternal kosong yang tak bergerak. Dengan kata lain jama'ah dan jam 'iyah NU telah dan terus menerus mengalami pengayaan atau pemiskinan ornamental, dan pergeseranfundamental (Effrat : 1972). Pengayaan ornamental terjadi terutama sejak NU telah menjadi partai politik ketika partai itu harus berhadapan dengan upaya mempengaruhi sikap dan partisipasi individual anggota (articulate down) partaipartai lainnya untuk merebutkan dukungan massa, baik menjelang pemilu maupun sesudahnya ketika politik massa sedang marak dengan membentuk organisasi-organisasi niven-nya hampir di semua lini (Muslimat NU, Pemuda 
Ansor, Fatayat NU, IPNU dan IPPNU, PMII dsb.). Sebaliknya ketika politik massa menyurut, terjadilah pemiskinan omamental, yang ditandai oleh tidak berfungsinya lagi organisasi massa tertentu (Pertanu, sarbumusi dan Lesbumi).

Pergolakan NU sampai dengan parohan pertama dasawarsa 1980-an telah dibahas secara mendalam oleh pengamat NU (Irsyam :1984), dan dinamika internal setelah NU kembali ke Khittah 1926 sampai dengan parohan pertama dasawarsa 1990-an ditelaah secara luas oleh (Van Brusinessen : 1997; Ida : 1995). Dari kedua tulisan itu terlihat adanya pembagian kekuasaan internal, yang mula-mula pada saat berdirinya bagian terbesar dipegang oleh faksi syuriyah (sampai pada tahun 1950-an) kemudian secara perlahan tetapi pasti bagain terbesar kekuasaan itu berada di tangan faksi politik (tanfidiyah) sampai parohan pertama dasawarsa 1980-an (Irsyam : 1984), dan terakhir bagian kekuasaan terbesar itu mulai direbut oleh faksi cendikia (Ida : 1995) generasi muda baru. Dalam menelaah pergolakan struktur di dalam NU, berbagai pengamat mempergunakan si stem yang berbeda.dan penekanannya yang berbeda.

Kebanyakan penulis menggunakan sistem "belah dua", misalnya kiai dan politisi (Adnan : 1982), sedangkan istilah faksi "cendekia" digunakan oleh Laode Ida (1995), faksi PBNU dan faksi cabang-cabang (Nakamura : 1982) dan kelompok tua dan kelompok muda. Penuilis yang menggunakan sistem "belah tiga" adalah Irsyam (1984) dan Ida (1995). Sedangkan Wahid, terutama setelah kembali ke khittah 1926, membagi unsur-unsur di dalam NU menjadi kelompok khittah murni, khittah plus dan khittah minus. Pengelompokan unsur-unsur, yang dilakukan oleh para penulis itu pada umumnya mengacu ke ketegangan hubungan di antara kelompok atau aksi-faksi yang seringkali berakar pada kepentingan politik jangka pendek.

Meski demikian para pengamat cenderung sampai pada kesimpulan yang hampir sama yakni bahwa perubahan "struktur sosial politik NU" adalah merupakan hasil dari interaksi antara dinamika internal yang terjadi di dalam jam 'iyah NU dengan perubahan sosial politik eksternal di lingkungan sekitaran $\mathrm{NU}$, yang keduanya bekerja secara dialektk, dan kadangkala bersambatan.

\section{Kubu-kubu Paradikmatik yang Berlaga}

Gus Dus (panggilan akrab Abdurrahman Wahid) dengan kesal pernah menyatakan bahwa sekarang ini terdapat setidaknya tiga kubu yang berlaga di dalam NU, yaitu kubu "khittah mumi", kubu "khittah plus" dan kubu "khittah minus" (Ida : 1995). Billah (1998) menjelaskan bahwa berbagai kubu sedang 
berlaga di dalam tubuh N U. Setidaknya a da tiga kubu besar, disamping percabangannya dan sempalan-sempalannya, bila dilihat dari kiblat (orientasinya) pada perubahan, yakni : (a) kubu pro kemapanan (anti perubahan) yang tidak menginginkan perubahan apapun dari kondisi dan situasi NU, oleh karena mereka menangguk keuntungan dan manfaat yang besar atas situasi "status quo" ini; (b) kubu pro-perubahan reformatoris, yangmenginginkan perubahanperubahan tingkat peralatan (instrumental), tanpa melakukan perubahan pada tataran nilai-nilai kebudayaan (kubu inovatif); dan (c) kubu pro-perubahan transformatoris, yang menghendaki baik perubahan nilai-nilai b udayanya (organisasi NU) maupun pada tataran peralatan kelembagaan organisasi NU (dalam versi Mertonian kubu ini disebut sebagai kubu pemberontak).

Sebagaimana dijelaskan di atas, bahwa pada awalnya faksi tanfidiyah hanya berfungsi dibidang admnistratif-organistoris, seluruh kebijakan keputusan berada pada faksi syuriyah, secara perlahan tapi pasti tanfidiyah mentrasformasikan peran $\mathrm{d}$ irinya tidak $\mathrm{l}$ agi hanya s ekedar melakukan administratif-organisatoris di bawah hegomoni' syuriyah ${ }^{2}$, melainkan juga melakukan dan mengukuhkan dirinya peran utamanya dalam bidang politik. Peran politik tanfidiyah ini memperoleh peluang untuk keluar dari hegomoni syuriyah, menurut Irsyam (1984) ini dipicu oleh adanya kekecewaan terhadap alokasi dan distribusi kekuasaan di dalam Masyumi tahun 1952, sehingga NU keluar dari Masyumi dan menjadi partai politik sendiri. Kesempatan emas ini dipergunakan dengan baik oleh faksi tanfidiyah untuk melangkah sebagai gerakan tandingan politisi tanfidiyah.

Para penulis mencatat bahwa keputusan NU untuk keluar dari Masyumi dan menjadi partai politik ini membawa dampak berupa munculnya faksi-faksi di dalam elite NU, yakni faksi syuriyah-pesantren non politisi, faksi syuriyah politisi dan faksi politisi tanfidiyah. Faksi syuriyah pesantren non politisi semakin lama semakin surut dan terpinggirkan seiring dengan semakin maraknya kegiatan politik NU, sebaliknya faksi syuriyah politisi memperoleh ruang dan peran yang cukup longgar ${ }^{3}$ ketika syuriyah dipimpin oleh Rois Aam $\mathrm{KH}$. Abdul Wahab Hasbullah yang mempunyai kecenderungan kuat untu mengutamakan politik. Akibatnya, sebagimana yang ditulis oleh Irsyam (1984: 87) syuriyah tidak lagi utuh karena para anggotanya masing-masing memiliki jalinan interaksi dengan politisi yan berbeda-beda. Faksi syuriyah politisi memiliki kepentingan yang terkait erat dengan kepentingan politisi tanfidiyah; Oleh karenanya disamping terjadi kemungkinan terjadi persekongkolan, perselingkuhan, juga muncul persaingan, ketegangan dan pertikaian untuk merebutkan kekuasaan di dalam organisasi ${ }^{4}$; Apalagi pada tahap ini muncul 
tenaga-tenaga y ang l ebih muda, serta tanfidiyah mulai pula melakukan perekrutan tenaga yang bukan berasal dari pesantren, bahkan rekrutmen para pemimpin itu mengesampingkan prosedur organisasi dan potensi pesantren, seperti dikatakan Irsyam (1984:107) Idham Chalid pun direkrut dengan caracara seperti itu, yakni melalui hubungan pribadi.

Dampak awal merosotnya pamor faksi syuriyah tersebut terasa sekali sampai sekarang, yaitu semakin mendominasinya peran faksi tanfidiyah di dalam organisasi NU.Akibat dari pergeseran-pergeseran yang terjadi itu pada tingkat struktural adalah bahwa personil politisi semakin bertambah banyak dan beragam yang tidak saja dari personil tanfidiyah, akan tetapi juga ditambah dengan pejabat-pejabat syuriyah yang melakukan peran politik. Irsyam (1984) mencatat bahwa syuriyah dan tanfidiyah sama-sama memainkan peran sebagai politisi, seperti kita lihat dalam banyak kasus. Bahkan kasus Peilihan Gubernur Jawa Timur peran syuriyah begitu nampak.

Mencermati apa yang digambarkan oleh Billah (1998), tentang berbagai kubu yang sedang berlaga di dalam organisasi NU cukup memberikan gambaran yang jelas. Bahkan ia katakana NU selalu diwamai persaingan perebutan kekuasaan internal.

Gambar / skema yang di buat oleh Billah (1998) memperlihatkan bahwa kubu pro-perubahan di dalam tubuh NU, yang menghendaki sosok sosial-politik $\mathrm{NU}$ yang baru, masih tetap menghadapi kubu pro-kemapanan dengan jumlah yang ditunjukan cukup besar dan pengaruhnya masih cukup kuat, syuriyahpolitisi, politisi penebeng, dan politisi parasit. Para politisi yang nyaris tidak mempunyai akses ke pesantren berupaya melakukan kegiatan articulate down (mencari dukungan ke bawah) dengan atau tanpa persekongkolannya syuriyahpoltisi, misalnya dilakukan dengan menyelenggarakan kelompok diskusi dan pelatihan politik atau membangun jaringan sendiri (umumnya yang dijaring adalah kelompok muda yang silau terhadap pamor politisi, atau yang kurang memiliki prospek dalam bidang professional).Kegiatan articulate across dilakukan dengan membangun $p$ ersekutuan-perskutuan baru b ersama mereka yang dipiggirkan atau yang terpental dari permainan politik diberbagai tingkat. Sedangkan para articulate up kurang berarti karena kemampuan konseptual kelompok ini kurang memadai dan kecanggihan artikulasainya rendah-meskipun sebagian anggota kelompok ni berahasil meraih patronase politik pada beberapa elite kekuasaan dalam birokrasi pemerintah atau pada kelompok militer (Billah :1998)., sehingga tidak membahayakan kubu-perubahan. Upaya kubu prokemapanan terutama yang dilakukan oleh faksi politisi untuk menggoyang kubu 
pro-perubahan, meskipun hanya sedikit mendatangkan ancaman serius bagi kubu pro-perubahan, akan tetapi seringkali juga merepotkan, apalagi bila dilihat jumlah orang dalam kubu pro-perubahan tidaklah cukup banyak, meski mempunyai pengaruh dan kemampuan artikulasi yang memadai. Manuver kasus SDSB pernah dimanfaatkan oleh kubu ini untuk menggoyang kepemimpinan Abdurrahman Wahid.

Upaya articulate down yang dilakukan oleh kubu pro-perubahan ini terlihat dari berbagai kegiatan halaqah, lokakarya, dan seminar yang diikuti oleh berbagai pesantren di Jawa mengenai berbagai hal dari yang bersifat refleksi teologis sampai persoalan sosial yang selalu muncul dan terus ditangkap oleh kubu ini.

\begin{tabular}{|c|c|c|c|c|}
\hline \multirow{2}{*}{$\begin{array}{c}\text { Knerja / } \\
\text { Kiblat }\end{array}$} & \multirow[b]{2}{*}{ Produktif } & \multirow[b]{2}{*}{ Reproduktif } & \multicolumn{2}{|c|}{ Non-produktif } \\
\hline & & & Penebeng & Parasit \\
\hline $\begin{array}{c}\text { Pro- } \\
\text { kemapanan } \\
:\end{array}$ & $(?)$ & $\begin{array}{l}\text { pesantren; syuriyah } \\
\text { non-politisi } \\
\text { \{pengaruh sedang\} }\end{array}$ & $\begin{array}{l}\text { Politisi; } \\
\text { syuriyah } \\
\text { politisi } \\
\text { (sangat } \\
\text { banyak) } \\
\text { (pengaruh } \\
\text { agak kuat }\end{array}$ & $\begin{array}{l}\text { unsur } \\
\text { politisi } \\
\text { (banyak } \\
\text { 'pengaruh } \\
\text { kurang) }\end{array}$ \\
\hline $\begin{array}{l}\text { Pro-perubahan } \\
\text { reformatoris }\end{array}$ & $\begin{array}{l}\text { Ksas pesantres non } \\
\text { politisi generasi } \\
\text { muda aktivis } \\
\text { liberal } \\
\text { (sedikit banyak) } \\
\text { \{pengaruh kuat }\end{array}$ & $\begin{array}{l}\text { unsur generası muda } \\
\quad \text { (sedikit) } \\
\text { \{pengaruh sedang\} }\end{array}$ & $\begin{array}{l}\text { unsur generast } \\
\text { muda } \\
\text { (sangat } \\
\text { banyak) } \\
\text { \{pengaruh } \\
\text { kurang\} }\end{array}$ & $\begin{array}{l}\text { unsur } \\
\text { generasi } \\
\text { muda } \\
\text { (sedikit? } \\
\text { \{pengaruh } \\
\text { kecil\} }\end{array}$ \\
\hline $\begin{array}{l}\text { Pro-perubhan } \\
\text { Transforma- } \\
\text { toris }\end{array}$ & $\begin{array}{c}\text { Cienerası muda } \\
\text { aktivis radikal } \\
\text { (sangat sedikit) } \\
\text { \{pengaruh } \\
\text { kurang\} }\end{array}$ & $\begin{array}{l}\text { unsur generast muda } \\
\text { (sangat sedikit) } \\
\text { \{pengaruh kurang\} } \\
\therefore\end{array}$ & $\begin{array}{l}\text { unsur generası } \\
\text { muda } \\
\text { (banyak) } \\
\text { \{pengaruh } \\
\text { kurang\} }\end{array}$ & $\begin{array}{l}\text { unsur } \\
\text { generasi } \\
\text { muda } \\
\text { (sedikit) } \\
\text { \{pengard) } \\
\text { kurang\} }\end{array}$ \\
\hline
\end{tabular}

$(\ldots)=$ Jumlah Pendukung $\{\ldots\}$ kuatnya pengaruh

Skema faksi-faksi yangsedang berlaga di dalam NU

\section{Kaitan eksternal}

Pada awal abad 20 ini lahir gerakan pembaharuan Islam Muhammadiyah dan Gerakan politik Sarekat Islam. Gerakan pembaharuan Islam ini dirasakan 
sebagai ancaman terhadap posisi $p$ ara kiai $d$ an umat Islam yang $d$ isebut tradisional di pedesaan, sehingga pertikaian di antara kubumodemis kaum pembaharu dạn kubu tradisionalis para kiai pesantren itu mencuat di dalam kongres Al Islam, baik di Yogyakarta pada tahun 1925 maupun di Bandung pada tahun 1926 (Alfian dalam Noer : 1991). Oleh karena itu banyak pengamat menyatakan bahawa NU adalah merupkan wujud dari gerakan tandingan terutama atas gerakan pembaharuan Islam dalam negeri (Irsyam : 1982); meskipun latar belakang internasional ikut berpengaruh (Bruinessen : 1997).

Gerakan pembaharuan itu berpasangan dan bersaingan dengan gerakan tandingannya dalam pergulatan kebudayaan, sosial dan juga politik (Billah :1998). Persaingan politik mencapai puncaknya ketika NU keluar dari Masyumi dan mendirikan partai sendiri, pertikaian semakin memburuk ketika Soekamo membubarkan dan melarang partai Masyumi, sedangkan NU justru mendukung konsepsi Soekarno, bahkan NU dengan tegas menyatakan Soekamo sebagai adalah waliy al amri al dharuri bi al syaukah, sehingga dengan gelar yang diberikan NU ini seringkali mendapat kritik yang cukup tajam dari lawan politiknya (Brusinessen : 1997 : 70-76).

Gerakan pasangan saling bersaingan itu nampak mengurangi ketegangan dan berusaha saling mendekat, atau setidaknya terjadi semacam gencatan senjata antara dasawarsa 70 -an dan awal 80 -an, salah satu dari upaya pendekatan ini adalah dibentuknya P3M, yang pada awalnya sebennamya merupakan wahana persekutuan antara berbagai aliran dalam Islam (kubu pembaharu dan kubu radisional) yang bertujuan mula-mula melibatkan pesantren di dalam proses pembangunan. Sifat sebagi persekutuan (aliansi) ditujukan oleh bergabungnya tokoh-tokoh dari berbagai aliran itu : Prof. Dawam Rahardjo, Dr. Adi Sasono (Muhammadiyah, Masyumi, HMI), Utomo Dananjaya (Pesis,PII), almarhum KH. Sholeh Iskandar (PUI,BKSPP), Masyumi; Abdurrahman Wahid, KH. Yusuf Hasyim, KH.Sahal Mahfudz, KH. Abdullah Syarwani, Nasihin Hasan (NU); Tuty Alawiyah. Meski demikian pada prakteknya dan akhimya P3M cenderung ke kelompok NU karena kebanyakan para pelaksananya adalah orang-orang Nu. Ketika P3M dipimpin direkturnya yang pertama yakni Nasihin Hasan kiblat ideologis-nya cenderung kurang jelas karena merupakan campuran dari unsur konservatisme dan reformisme, akan tetapi ketika kemudian ia digantikan oleh Masdar Farid Mas'udi, ideologinya-secara berangsur-angsur bergerakkearah ideologi transformatoris, dalam arti ia berkiblat pada perubahan sosial dan kebudayaan yang mendasar, antara lain menyentuh segi-segi ajaran teologi dan ajaran ahlussunnah wal jama'ah (Billah :1998). 
Gerakan saling mendekati tersebut kembali memanas pada paohan dasawarsa 80-an ketika kesenjangan antara keduanya kembali menganga, lebihlebih setelah kelahiran ICMI pada awal tahun 1990an yang kemudian ternyata lebih banyak merekrut anggotanya dari kubu pembaharu; dan Gus Dur secara lantang saat itu melontarkan kritiknya terhadap ICMI (Billah :1998). Kemudian kembali sedikit agak mesra ketika masing-masing saling mendekati untuk menghalangi Megawati Soekamoputri maju ke kursi Presiden pada tahun 1999, sekalipun justru gerakan ini menjadi pemicu perpecahan yang lebih dahsyat. Kekecewaan kedua belah pihak tak dapk dihindarkan, masing-masing dari jama'ahnya saling marah. Masyarakat Situbondo yang notabenenya adalah warga NU, yang sangat fanatic terhadap tokoh NU (kiai) mereka marah dengan menebang pohon untuk dirobohkan, sehingga membuat jalanan macet yang merugikan masyarakat banyak.

Akhir-akhir ini, nampaknya upaya untuk saling mendekati semakin nampak. Tokoh Modernis semisal Syafi'I Ma'arif, Amin Rais dan Nurcholish Madjid sering b erkunjung ke $k$ antong-kantong NU. Terlepas apakah ini merupakan kepntingan sesaat, karena ingin mendaptkan dukungan politik atau tidak, tapi yang jelas gerakan tersebut digulirkan. Adalah KH. Hasyim Muzadi, yang notabenenya dia seorang ketua tanfidiyah PBNU, yang sering disebutsebut sebagai calon presiden, sekalipun belum jelas partai apa yang akan mencalonkan, ia sering mengadakan pertemuan dengan tokoh-tokoh modernis. Selinthinga gandeng rentengnya Hasyim Muzadi dengan Syafi'I Ma'arif sudah bukan rahasia lagi seluruh lapisan, baik warga Muhammadiyah dan NU kiranya mereka sudah menyaksikan.

Akan tetapi ada yang mengatakan, dari sejarahnya tidak pernah kubu modernis dan tradisionalis bisa gandeng rentheng, dalam arti yang sebenamya. Gandeng renteng ini pasti bersifat semu dan sementara karena masing-masing di antara keduanya sebenamya ingin mencapai tujuan yang tidak mungkin bisa dipertemukan yakni politik. Maka sangat wajar jika dikatakan, apabila NU yang mendominasi birokrasi, Muhammadiyah adalah pesaingnya dan sebaliknya.

\section{Kubu Ideologis yang Berlaga, dan Faksi yang Berlaga}

Uraian di atas menunjukkan bahwa NU tidak berada di dalam ruang yang kosong, demikian juga dinamika pergolakannya tidaklah tanpa memiliki kaitan dengan eksternal. Irsyam (1984) dan Ida (1995) dan sejumlah pengamat lain (Bruinessen : 1997) memaparkan kaitan antara dinamika internal NU dengan unsur-unsur eksternal antara lain lewat apa yang disebut sebagai 
patronase politik. Kelompok eksternal mana yang menjalin hubungan dengan atau di cantholi oleh faksi-faksi yang secara ekstemal bertikai itu ? Faksi yang berbeda mencoba memilih cantholan yang berlainan. Di dalam politik Indonesia mutakhir, setidaknya ada tiga buku ideologis yang bersaing (Robinson dalam Billah :1998), yaitu (a) kubu teknokrat liberal yang berkiblat pada pasar bebas (free market-oriented liberal-technocrat); (b) kubu perancang e konomi nasionalis yang berkiblat pada negara organic-statist (nationalist-centered economicplanners), dan (c) kubu nasionalis kerakyatan (populist-nationalist) Ketiga kubu ideologis ini melahirkan actor politik yang saling bersaing untuk mempengruhi pengambilan kebijakan ekonnomi dan pembngunan selama periode pasca '65 (Robinson \& Hadiz dalam Billah : 1998). Kubu liberal terdiri dari ekonom neo-klasik berpendidikan Barat yang dulu berkumpul di lembagalembaga perencanaan seperni Bappenas dan Departemen Keuangan.

Kubu kedua cenderung yakin pada pandangan organic stutism dan percaya pada sentralisasi kekuasaan dan perencanaan ekonomi terpusat pada Negara nasionalis. Kubu ini terdiri dari berbagai faksi yang saling bersaing. Faksi pertama adalah militer, yang meskipun merupakan organisasi kompak, akan tetapi di dalamnya terdapat suu-sub faksi, yakni angkatan ' 45 yang erdiri dari sayap militer yang politis-pragmatis, dan sayap yang pricipled, dan perwiraperwira baru enerasi muda pasca angkatan ' 45 ( Jenkins, Britton dalam Billah: 1998).

Kubu nasionalis populis menentang apa yang dianggapnya free fight capitalism, dan berpendapat bahwa Negara memiliki tanggung jawab atas kepentingan rakyat, tetapi juga menentan sengit kerajaan-kerajaan politik dan ekonomi yang memperoleh keuntungan dari perlindungan Negara. Kubu kurang memiliki basis kekuatan yang kuat (Billah : 1998).

\section{Tarikan dari Luar atas Gerakan Internal NU}

Di gambarkan oleh Billah (1998), bahwa sosok sosial politik NU dari masa kemasa menjadi selalu aneh dan rumit bilamana dikaitkan dengan kubu ideologis dan faksi-faksinya yang ada di dalam peta politik. Para politisi NU mencari patronase politik dari berbagi faksi yang berbeda dari kubu organicstatisin, seolah hendak mendemontrasikan secara terang-terang etika politik yang mereka yakini betul kebenarannya yaitu " di dalam politik, tiada kawan dan lawan yang permanent, yang ada adalah kepentingan yang permanent". Etika politik semacam ini seringkali diungkapkan oleh para politisi $\mathrm{NU}$, dan dipergunakn oleh mereka untuk menyembunyikan kepentingan mereka 
sendiri (Billah :1998). Doktrin semacam ini akan membuka kemungkinan terjadinya perubahan yang cepat persekutuan-persekutuan yang dibuat.

Dalam banyak kasus politisi NU, sering dinilai berwajah dua, hal ini bisa difahami karena memang adanya doktrin seperti tersebut, sekalipun tidak banyak orang tahu dari mana dan siapa yang membuat doktrin itu, yang jelas sampai saat ini doktrin tersebut atau paling tidak kita bisa melihat implikasi perilaku politisi NU saat dari masa kemasa yang selalu berubah-ubah.

\section{Footnotes}

' Hegomoni adalah merupakan konsep yang terpenting di dalam pemikiran Grasmci. Pengertian hegomoni (eugemonia) sebenamya untuk pertama kalinya diterapkan dalam sejarah Yunani Kuno yang berarti posisi yang diklaim oleh negara Negara kota (city s tate atau polis) terhadap n egara-negara lain . Selanjutnya hegemoni diartikan sebagai suatu kepemimpinan dari suatu negara tertentu terhadap negara-negara lain yang terkait secara ketat ataupun longgar ke dalam kesatuan Negara pemimpin. Sedangkan Mao Tse Tung menggunakan hegomonisme untuk menandai satu dominasi dari suatu Negara atas yang lainnya tetapi yang bukan imperialisme; dan Lenin menggunakan kata itu untuk menunjuk kemimpinan politik di dalam revolosi yang demokratis yang didasarkan pada persekutuan dengan bagian-bagian dari petani, atauyang oleh Grasmci digunakan untuk menggambarkan bagaimana dominasi dari satu klas atas klas yang lain dicapai lewat rangkaian ramuan alat-alat $\mathrm{p}$ olitis dan ideologis (how the domination of one class over others is echieved by a combination of political and ideological means). Ideologi dominant atau hegominis ini dapat menyediakan suatu pandangan dunia yang lebih koheren dan sistematis yang bukan saj mempengaruhi massa rakyat akan tetapi juga menyediakan landasan organisatoris bagi lembag sosial.

2 Peran syuriyah sebagai politisi ini diawali oleh KH. Abdul Wahab Hasbullah ketika menjabat Rois Aam Syuriyah yang dianggap mempunyai ecenderungan politik yang kuat untuk mengutamakan politik dari pada hokum Syar'i. Secara lebih transparan, Irsyam mengatakaan bahwa dalam banyak hal syuriyah di bawah kepemimpinan Abdul WahabHasbullah itu terlarut dalam peran politisi. Syuriyah seringkali menyusun hukum syar'i dengan cara talfiq, yaitu memetik -metik hokum dari keempat madzhab tanpa memperhatikan sistematikanya. Malahan tidak jarang hukum syar'i yang disusun pada waktu itu hanya berdasar pada shahabat Nabi (Irsyam : $1984: 87-88$ ). 
${ }^{3}$ Irsyam (1984) mencatat bahwa syuriyah dan tanfidiyah sama-sama memainkan peran sebagai politisi, artinya batas yang tegas dalam tradisi pesantren, yang membedakan dan sekaligus mengatur hubungan antara kiai dan santri di dunia pesantren menjadi kabur (atau perlahan hilang sama sekali) ketika dipergunakan di dalam tubuh NU untuk mengatur hubungan antara ulama dan politisi.

${ }^{4}$ Irsyam (1984) menyebutnya bahwa ketertlibatan syuriyah bukanlah sekedar hanya keterlibtan dengan masalh-masalah politik saja tetapi juga keterlibatan dalam pengertian bahawa ulamapun melakukan aliansi dengan kalangan politisi. Selanjutnya ia menyatakan bahwa para politisi yang sebetulnya dalam posisi subordinasi para ulama dapat melakukan penetrasi ke kalangan syuriyah (p. 96).

\section{DAFTAR PUSTAKA}

Bruinessen, Van Martin, NU : tradisi, relasi-relasi kekuasaan kuasa, dan mpencarian wacana baru, LKIS Yogyakarta 1997.

Billah, MM, Pergolakan NU dan Kelompok Islam, (artikel) Tashwirul Afkar, Edisi No 2 Mei 1998 Lakspesdam NU Jl. Kunirigan Barat Jakarta.

Irsyam, Mahrus, Ulama dan Politik, Yayasan Perkhidmatan Jakarta 1984.

Ida, Laode, Dinamika Internal NU setelah Kembali ke Khittah 1926, Tesis PPS UI Jakarta 1995.

Marijan, Kacung, Quo Vadis NU : Setelah Kembali ke Khittah 1926, Erlangga Jakarta 1992

Mulkhan, Abdul Munir, Runtuhnya Mitos Politik Santri, Sipress Yogyakarta 1992

Thaba, Abdul Aziz, Islam dan Negara dalam Politik Orde Baru, Gema Insani Press Jakarta 1996.

Wahid, Abdurrahman, Muslim di Tengah Pergumulan, Lepenas Jakarta 1984 .

Wahid, Abdurrahman, NU dan Islam di Indonesia Dewasa ini, Prisma, XII (4) 1984.

Yusuf, Slamet Effendy, et.al. Dinamika Kaum Santri : Menelusuri Jejak dan Pergolakan Internal NU, CV. Rajawali Jakarta 1983 